\title{
Astmos gydymas vartojant Symbicort
}

Laura Tamašauskienė, Ieva Bajoriūnienė

LSMU MA Pulmonologijos ir imunologijos klinika

\section{IVADAS}

Astma yra lètinè kvẻpavimo takų uždegimo liga, kuria serga 1-18 proc. gyventoju ịvairiose šalyse [1]. Apskaičiuota, kad pasaulyje ja serga $300 \mathrm{mln}$. žmonių [2]. Daugelyje šaliu astmos paplitimas nuolat didèja, ypač vaiku grupeje [2]. Liga pasireiškia švokštimu, dusuliu, krūtinès veržimo pojūčiu, kosuliu. Simptomų dažnis ir intensyvumas dažnai priklauso nuo provokuojančių veiksnių: fizinio aktyvumo, sąlyčio su alergenu ar kitu dirgikliu, oro sąlygu pasikeitimo, virusinès kvejpavimo takų infekcijos [1]. Simptomai gali išnykti savaime ar vartojant vaistus, tačiau net ir nesant klinikinių astmos požymių, padidèjęs kvėpavimo takų reaktyvumas $\mathfrak{i}$ tiesiogini ar netiesiogini dirgikli ir lètinis uždegimas kvèpavimo takuose išlieka nuolat [1]. Astmos diagnozė grindžiama klinikiniais simptomais, detalia anamneze ir plaučiu funkcijos tyrimais [1].

Astma pablogina paciento gyvenimo kokybę bei didina valstybès išlaidas, skirtas sveikatos paslaugoms: astma riboja pacientų kasdieni aktyvumą, yra viena pagrindinių mokyklos ir darbo praleidimo priežasčių, o ekonomiškai išsivysčiusios valstybès išleidžia $1-2$ proc. visų sveikatos paslaugoms skirtų lěšų astmos gydymui [2]. Išlaidos blogai kontroliuojamos astmos gydymui yra didesnès [2]. Dèl šiu priežasčių labai svarbu anksti diagnozuoti ligą, parinkti optimalu gydymą ir siekti geros astmos kontrolès.

\section{KAS LEMIA EFEKTYVU ASTMOS GYDYMA}

Astmos kontrolès įvertinimas apima simptomų pasireiškimo sunkumą ir dažnị bei blogos astmos prognozės rizikos veiksnių nustatymą (lentelè). Tam, kad astma būtų tinkamai kontroliuojama, reikia skirti tinkamą gydymą, kuris parenkamas atsižvelgiant ị simptomų dažnị ir intensyvumą [1]. Labai svarbu mokyti pacientą. Efektyviausia tai pasiekti tada, kai pacientas ir gydytojas bendrauja kaip partneriai [1]. Pirmiausia gydytojas turi suteikti informacijos apie ligą: jos priežastis, provokuojančius veiksnius, išsivystymą, simptomus, gydymo metodus ir prognozę [1]. Informacija turi būti pateikiama taip, kad pacientas ją suprastų; rekomenduojama duoti rašytinių šaltinių, nuorodų internete [1]. Reikia išaiškinti pacientui, kodèl būtina griežtai laikytis nurodyto gydymo režimo, kaip veikia jo vartojami vaistai, kodèl reikia reguliariai lankytis gydymo įstaigoje. Tyrimai rodo, kad apie 50 proc. vaikų ir suaugusiụjų, sergančių astma, nevartoja vaistu taip, kaip yra nurodyta [3]. Svarbu paraginti pacientą pačiam stebėti ir pasižymèti astmos simptomus, provokuojančius veiksnius, ligos paūmėjimus, vartojamus vaistus, as- tmos kontrolès lygit. Tyrimai rodo, kad šios priemonès nuo 1/3 iki 2/3 sumažina hospitalizavimo dèl astmos paūmèjimu, apsilankymų skubiosios pagalbos skyriuje, neplanuotų vizitu pas gydytoją, praleistu dienų darbe ir mokykloje bei naktiniu prabudimų skaičiu [1].

Vienas svarbiausių dalyku - parinkti inhaliatorių ir išmokyti pacientą tinkamai ịkvejpti vaistą [1]. Veikliosios medžiagos patekimą í plaučius nulemia daug veiksnių: vaisto dalelių dydis, kvépavimo taku anatomijos ypatumai, įkvèpimo technika [6]. Netinkama vaisto įkvèpimo technika blogina astmos kontrolę, didina ligos paūmèjimų ir nepageidaujamų vaisto reakcijų riziką [4]. Daugelis žmonių, naudojančių inhaliatorius, net nežino, kad netinkamai ikvepia vaistą [1]. Apie $70-80$ proc. pacientu nemoka taisyklingai naudoti inhaliatoriaus, ir tik nedidelè medicinos personalo darbuotojų dalis sugeba tinkamai išaiškinti ir parodyti, kaip tą daryti [1]. $2014 \mathrm{~m}$. V. Ninane ir kt. pristatė tyrimą, kurio metu buvo vertinama taisyklingo inhaliatoriaus naudojimo svarba gydant astmą [5]. Rezultatai parodè, kad inhaliatoriaus tipas ir taisyklingas ¡kvèpimas yra toks pats svarbus kaip ir veiklioji vaisto medžiaga [5]. Siekiant pagerinti astmos kontrolę, rekomenduojama pacientams pateikti vaizdinès medžiagos, kurioje būtu schemos su paaiškinimais, kaip taisyklingai ikvejpti vaistą, pirmiausia išmokyti pacientą naudotis inhaliatoriumi, ivertinti, ar jis tai daro teisingai, ir tik tada išrašyti vaisto receptą [5].

Optimalus vaisto dalelių dydis, kurio reikia, kad įkvèp-

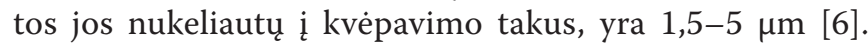
Didesnès nei $5 \mu \mathrm{m}$ dalelès patenka ị burną ir ryklę, todèl didèja nepageidaujamo vaisto poveikio rizika ir mažeja jo efektyvumas [6]. ¿̨kvepiant mažesnes nei 1,5 $\mu \mathrm{m}$ daleles, apie 40 proc. padidejja rizika jas iškvèpti atgal, taip mažesnis kiekis vaisto patenka i kvėpavimo takus [6]. Sausų milteliu inhaliatoriaus Symbicort sudettyje esančios veikliosios medžiagos dalelių dydis yra mažesnis nei $5 \mu \mathrm{m}$, ¡kvèpus jas, didelis kiekis 1-3 $\mu \mathrm{m}$ dydžio dalelių patenka tiek $\mathfrak{i}$ centrinę, tiek ị periferinę kvejpavimo takų dalis [6].

\section{SYMBICORT VAIDMUO GYDANT ASTMĄ}

Symbicort - sausu milteliu inhaliatorius, kurio veikliosios medžiagos yra gliukokortikoidas budezonidas, pasižymintis uždegimą slopinančiu poveikiu, ir ilgai veikiantis beta 2 agonistas formoterolis, kuris greitai ir ilgam atpalaiduoja bronchu lygiuosius raumenis. Šis vaistas skirtas suaugusiesiems ir 12-17 metu paaugliams reguliariam astmos gydymui [7]. 
Lentelè. Suaugusiujų, paauglių ir 6-11 m. vaikų astmos kontrolès ivertinimas pagal GINA (angl. Global initiative of asthma) [1]

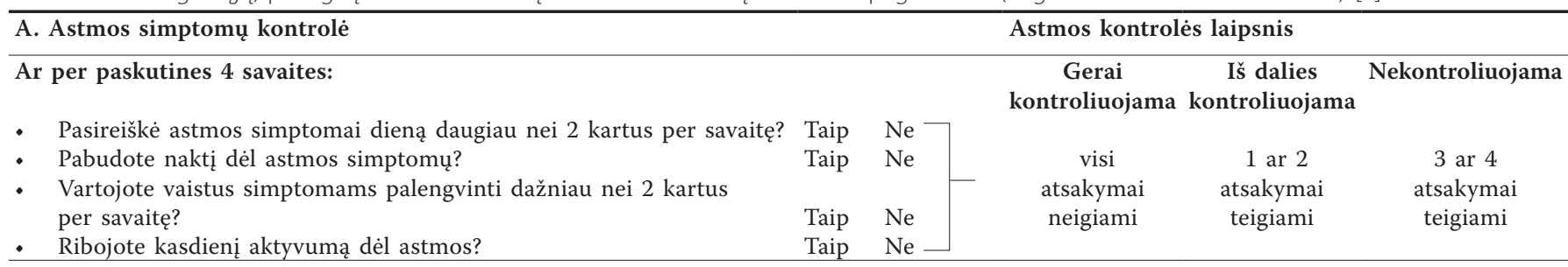

B. Blogos astmos prognozès rizikos veiksniai

İvertinti rizikos veiksnius reguliariai, ypač tiems pacientams, kuriems paūmèjimai dažni.

Ivertinti $\mathrm{FEV}_{1}$ gydymo pradžioje, praejjus 3-6 mèn. po gydymo pradejjimo, vẻliau - periodiškai.

Modifikuojami nepriklausomi astmos paümèjimo rizikos veiksniai:

- Nekontroliuojami astmos simptomai.

- Dažnas trumpai veikiančių beta 2 agonistų vartojimas.

- Netinkamas inhaliuojamųjų gliukokortikoidų vartojimas (netaisyklinga įkvèpimo technika, nereguliarus vaisto vartojimas, gydytojo neskirtų vaistų vartojimas).

- Mažas $\mathrm{FEV}_{1}$, ypač $<60$ proc.

- Psichologinès ir socioekonominès problemos.

- Rūkymas, sąlytis su astmą skatinančiais alergenais.

- Kitos ligos: nutukimas, rinosinusitas, maisto alergija.

- Skrepliuose ir kraujyje nustatyta eozinofilija.

- Nèštumas.

Kiti svarbūs nepriklausomi astmos paūmejjimo rizikos veiksniai:

- Intubacija ar gydymas intensyviosios terapijos skyriuje nuo astmos.

- Daugiau nei vienas astmos paūmèjimas per paskutinius 12 mèn.

Nuolatinio plaučiu funkcijos sutrikimo rizikos veiksniai:

- Nepakankamas gydymas inhaliuojamaisiais gliukokortikoidais.

- Rūkymas, sąlytis su kenksmingais chemikalais.

- Mažas pradinis $\mathrm{FEV}_{1}$, nuolatiné skrepliụ hipersekrecija, skrepliuose ir kraujyje nustatyta eozinofilija.

Vaistu nepageidaujamo poveikio rizikos veiksniai:

- Sisteminio: dažnas geriamųjų gliukokortikoidų vartojimas, ilgalaikis didelių dozių inhaliuojamųjų gliukokortikoidų vartojimas, P450 inhibitorių vartojimas.

- Vietinio: didelių dozių inhaliuojamųjų gliukokortikoidų vartojimas, netaisyklinga vaisto ikvejpimo technika.

Symbicort galima skirti dviem būdais: tik palaikomajam gydymui ir kartu palaikomajam gydymui bei simptomams palengvinti [7]. Skiriant tik palaikomąji gydymą, suaugusiesiems ir paaugliams rekomenduojama vartoti vaistą po 1 ar 2 inhaliacijas 2 kartus per parą, o atsiradus simptomams - vartoti trumpai veikianti beta 2 agonistą. Jei Symbicort yra skiriamas kartu ir simptomams lengvinti, pacientas ši vaistą turi vartoti ir tada, kai atsiranda astmos klinikinių požymių [7]. Šis metodas vadinamas SMART [8].

2007 m. atliktame klinikiniame tyrime buvo lyginamas efektyvumas budezonido/formoterolio ir salmeterolio/flutikazono kartu su trumpai veikiančiu beta 2 agonistu [8]. Tyrime dalyvavo 2309 pacientai, kurie patyrè astmos paūmejjimą per pastaruosius vienerius metus. Dalis pacientu gavo gydymą budezonidu/formoteroliu $160 / 4,5 \mu \mathrm{g}$ po 2 ikvejpimus 2 kartus per dieną ir pagal poreiki astmos simptomams slopinti, kita dalis - salmeteroliu/flutikazonu 50/500 $\mu \mathrm{g} 2$ kartus per dieną ir terbutalinu pagal poreikị. Rezultatai parodè, kad laikas iki pirmojo paūmèjimo grupèse nesiskyrè, tačiau gydymas budezonidu/formoteroliu statistiškai reikšmingai labiau sumažino bendrąji paūmèjimų skaičių, palyginti su gydymu salmeteroliu/flutikazonu (atitinkamai 25 ir 31 atvejų 100 pacientu per metus) bei hospitalizavimo dèl astmos riziką [8]. Kito tais pačiais metais atlikto klinikinio tyrimo metu buvo lygintas efektyvumas budezonido/ formoterolio, salmeterolio/flutikazono kartu su terbutali- nu ir budezonido/formoterolio kartu su terbutalinu [9]. Tyrime dalyvavo 3335 pacientai, sergantys astma, kuriu vidutinis FEV1 - 73 proc., o vidutine inhaliuojamųju gliukokortikoiduc paros dozé - $745 \mu \mathrm{g}$ [9]. Tyrimo rezultatai parodè, kad gydymas budezonidu/formoteroliu SMART metodu statistiškai reikšmingai pailgino laiką iki pirmojo sunkaus paūmejjimo, kurị reikia gydyti stacionare ir vartoti geriamųju gliukokortikoidų, palyginti su kitais gydymo būdais [9]. Pacientai, šiuo metodu vartoję vaistą tiek palaikomajam gydymui, tiek simptomams mažinti, suvartojo mažiau gliukokortikoidų, palyginti su tais, kurie buvo gydomi kitais inhaliatoriais. Budezonido/formoterolio vartojimas palaikomajam gydymui ir simptomų malšinimui užtikrino panašią astmos kontrolę kaip ir budezonidas/formoterolis bei salmeterolis/flutikazonas, vartojami palaikomajam gydymui kartu su terbutalinu simptomams malšinti [9]. Ankstesni klinikiniai tyrimai taip pat parodè, kad budezonidas/formoterolis vartojami SMART metodu pailgina laiką iki pirmojo paūmèjimo, sumažina sunkių paūméjimų riziką, hospitalizavimo dèl astmos skaičių, pagerina simptomų kontrolę, sumažina naktinių pabudimų skaičių, pagerina plaučių funkciją, sumažina paros inhaliuojamųjų gliukokortikoidų kiekị [10-11].

Klinikiniu tyrimu metu pacientams, vartojusiems Symbicort, nepastebėta daugiau nepageidaujamų reakcijų nei kitus vaistus gavusiems tiriamiesiems, dauguma šalutinių reakcijų buvo nesunkios $[8,9]$. 


\section{ASTMA SERGANČIŲ PACIENTŲ PRIEŽIŪRA}

Gydant astmą, siekiama geros simptomų kontrolès, normalaus kasdienio paciento aktyvumo, paūmejjimų rizikos sumažinimo ir normalios plaučių funkcijos užtikrinimo [1]. Tam, kad numatyti tikslai būtų pasiekti, reikia parinkti tinkamą vaistą, paaiškinti pacientui apie reguliaraus vaistų vartojimo svarbą, taisyklingą ikvèpimo techniką ne tik diagnozavus astmą, bet ir vẻliau, iprastinių vizitų metu. Kiekvieno vizito metu rekomenduojama patikrinti, ar pacientas moka taisyklingai naudotis inhaliatoriumi, paklausti, ar tikrai vartoja vaistus taip, kaip nurodyta, vertinti astmos aktyvumą, periodiškai - plaučių funkcijos rodiklius [1].

Vizitų pas specialistą dažnis yra individualus, nustatomas atsižvelgiant $\mathfrak{i}$ astmos kontrolès laipsni, atsaką i gydymą. Rekomenduojama, kad pacientas apsilankytų pas gydytoją praejus 1-3 mèn. nuo gydymo pradžios, vèliau - kas 3-12 mèn., o po paūmèjimo - per vieną savaitę [1].

Dauguma pacientų, sergančių astma, yra sẻkmingai prižiūrimi šeimos gydytojų, tačiau kai kuriais atvejais reikalinga papildoma gydytojo pulmonologo ar alergologo-klinikinio imunologo konsultacija. Pagal GINA $2015 \mathrm{~m}$. rekomendacijas, tai būtina, kai astmos diagnozè yra abejotina, esant didelei kitų ligų, sukeliančių paciento simptomus, tikimybei, lètinès infekcijos požymiams, ịtariant profesinę astmą [1]. Specialisto konsultacija rekomenduojama ir tais atvejais, kai ligos simptomai yra nekontroliuojami, kartojasi paūmejjimai, bloga plaučių funkcija, pacientas dažnai patenka ì skubiosios pagalbos skyrių, nepaisant reguliaraus vaistų vartojimo ir taisyklingos įkvėpimo technikos, pasireiškia sunkūs astmos simptomų priepuoliai, kuriuos tenka gydyti intensyviosios terapijos skyriuje ir (ar) taikant dirbtinę plaučių ventiliaciją, yra buvusi anafilaksija arba maisto alergijos simptomų, pasireiškusios nepageidaujamos vaistų reakcijos, reikalingas ilgas ir (ar) dažnas gydymas geriamaisiais gliukokortikoidais [1]. 6-11 m. vaikai turi būti siunčiami gydytojo pulmonologo ar alergologo-klinikinio imunologo konsultacijos, kai abejojama astmos diagnoze, išlieka astmos simptomai ir paūmejjimai reguliariai ir taisyklingai vartojant vaistus per inhaliatorių, pasireiškia nepageidaujamas vaistų poveikis, yra maisto alergijos simptomų [1].

\section{APIBENDRINIMAS}

Astma yra dažna lètinè kvẻpavimo takų uždegimo liga. Jos diagnozė grindžiama klinikiniais simptomais, detalia anamneze ir plaučių funkcijos tyrimais. Netinkamai gydoma astma verčia pacientus riboti savo kasdieni aktyvumą, dažnai neatvykti ì darbą ar mokyklą. Astma, ypač nekontroliuojama, didina išlaidas, skirtas sveikatos priežiūrai.

Efektyviam astmos gydymui svarbu paciento mokymas, tinkamas inhaliatoriaus parinkimas ir taisyklinga ikvėpimo technika.
Sausų miltelių inhaliatoriaus Symbicort sudètyje esančios veikliosios medžiagos dalelių dydis yra optimalus, todèl ịkvèptos lengvai patenka tiek i centrinę, tiek i periferinę kvėpavimo takų dalis. Symbicort veikliosios medžiagos yra gliukokortikoidas budezonidas ir ilgai veikiantis beta 2 agonistas formoterolis. Ši vaistą galima skirti tik palaikomajam gydymui bei kartu palaikomajam gydymui ir simptomams palengvinti. Klinikiniai tyrimai rodo, kad šis vaistas, vartojamas ir palaikomajam gydymui, ir simptomu palengvinimui, yra patogus pacientui, saugus ir efektyviai slopina astmos simptomus, sumažina laiką iki paūméjimo ir paūmẻjimų riziką. Taikant ši gydymo būdą, suvartojama mažiau inhaliuojamųjų gliukokortikoidų.

Pagrindiniai astmos gydymo tikslai yra gera simptomų kontrolè, normalus kasdienis paciento aktyvumas, nedidelè paūmèjimų rizika ir normali plaučių funkcija. Tam, kad būtų pasiekta gera ligos kontrolè, reikia parinkti tinkamą vaistą ir inhaliatorių, paaiškinti pacientui apie reguliaraus vaistų vartojimo svarbą, taisyklingą ịkvejpimo techniką, kiekvieno vizito metu patikrinti, ar pacientas moka taisyklingai naudotis inhaliatoriumi, vertinti astmos aktyvumą. Apsilankymų pas gydytoją skaičius nustatomas individuliai. Rekomenduojama, kad pacientas apsilankytu pas gydytoją praejus 1-3 mèn. nuo gydymo pradžios, vẻliau - kas 3-12 mẻn., o po paūmẻjimo - per vieną savaitę.

Gerai astmos kontrolei būtinas bendradarbiavimas tarp gydytojo ir paciento bei saugaus, efektyvaus ir patogaus gydymo būdo parinkimas.

\section{LITERATŪRA}

1. From the Global Strategy for Asthma Management and Prevention, Global Initiative for Asthma (GINA) 2015. Available from: http://www.ginasthma. org/.

2. From the Global Strategy for Asthma Management and Prevention, Global Initiative for Asthma (GINA) 2014. Available from: http://www.ginasthma. org/.

3. Boulet LP, Vervloet D, Magar Y, Foster JM. Adherence: the goal to control asthma. Clin Chest Med. 2012;33(3):405-17

4. Melani AS, Bonavia M, Cilenti V, Cinti C, Lodi M, Martucci P, Serra M, Scichilone N, Sestini P, Aliani M, Neri M; Gruppo Educazionale Associazione Italiana Pneumologi Ospedalieri. Inhaler mishandling remains common in real life and is associated with reduced disease control. Respir Med. 201;105(6):930-8.

5. Ninane V, Brusselle GG, Louis R, Dupont L, Liistro G, De Backer W, Schlesse $M$, Vincken $W$. Usage of inhalation devices in asthma and chronic obstructive pulmonary disease: a Delphi consensus statement. Expert Opin Drug Deliv. 2014;11(3):313-23.

6. Demoly $\mathrm{P}$, Hagedoorn $\mathrm{P}$, de Boer AH, Frijlink HW. The clinical relevance of dry powder inhaler performance for drug delivery. Respir Med. 2014;108(8):1195-203.

7. Valstybinè vaistu kontrolès tarnyba. Symbicort. Availabe at URL: http:// www.vvkt.It/Vaistu-registracija.

8. Bousquet J, Boulet LP, Peters MJ, Magnussen H, Quiralte J, Martinez-Aguilar $\mathrm{NE}$, Carlsheimer A. Budesonide/formoterol for maintenance and relief in uncontrolled asthma vs. high-dose salmeterol/fluticasone. Respir Med. 2007;101(12):2437-46

9. Kuna P, Peters MJ, Manjra Al, Jorup C, Naya IP, Martínez-Jimenez NE, Buhl R. Effect of budesonide/formoterol maintenance and reliever therapy on asthma exacerbations. Int J Clin Pract. 2007;61(5):725-36.

10. O'Byrne PM, Bisgaard H, Godard PP, Pistolesi M, Palmqvist M, Zhu Y, Ekström T, Bateman ED. Budesonide/formoterol combination therapy as both maintenance and reliever medication in asthma. Am J Respir Crit Care Med. 2005;171(2):129-36

11. Rabe KF, Pizzichini E, Ställberg B, Romero S, Balanzat AM, Atienza T, Lier $\mathrm{PA}$, Jorup $\mathrm{C}$. Budesonide/formoterol in a single inhaler for maintenance and relief in mild-to-moderate asthma: a randomized, double-blind trial. Chest. 2006;129(2):246-56.

Publikaciją remia AstraZeneca $739,910.011 / 04 / 15 / \mathrm{LT}$ 